\title{
Discovery of clinoenstatite in garnet pyroxenites from the Dabie-Sulu ultrahigh-pressure terrane, east-central China
}

\author{
Ru Y. Zhang, ${ }^{1}$ Yen H. ShaU, ${ }^{2}$ JUhn G. LIOU, ${ }^{1}$ AND Ching H. Lo ${ }^{3}$
}

\begin{abstract}
'Department of Geological and Environmental Sciences, Stanford University, Stanford, California 94305, U.S.A. ${ }^{2}$ Department of Marine Resources, National Sun Yat-sen University, Kaohsiung 80424, Taiwan, R.O.C. ${ }^{3}$ Department of Geosciences, National Taiwan University, Taipei 106, Taiwan, R.O.C.
\end{abstract}

\begin{abstract}
Transmission electron microscopy (TEM) reveals that some enstatites from garnet-pyroxenites in the Chinese Dabie-Sulu ultrahigh-pressure (UHP) terrane consist of intimate intergrowths of orthoenstatite (OREN) and clinoenstatite (CLEN), and some grains of pyroxene $(\mathrm{MgFe})_{2} \mathrm{Si}_{2} \mathrm{O}_{6}$ exhibit inclined extinction. These garnet pyroxenites are enclosed in coesite-bearing eclogite or interlayered with harzburgite and omphacitite. They contain garnet $\left(\operatorname{Prp}_{54}\right.$ to $\left.\operatorname{Prp}_{73}\right)$, "enstatite" $\left(\operatorname{En}_{85}\right.$ to $\mathrm{En}_{92}$ ), magnesite, and titanomagnetite (Sulu sample) or clinohumite (Dabie sample), and recrystallized at about 4.0-6.5 $\pm 0.2 \mathrm{GPa}, \sim 750 \pm 50^{\circ} \mathrm{C}$. All clinoenstatite lamellae in the host orthoenstatite have even numbers of $9 \AA$ (100) fringes without twins, and are oriented parallel to (100) of the host. The lamellae and host phases have nearly identical $(\mathrm{MgFe})_{2} \mathrm{Si}_{2} \mathrm{O}_{6}$ compositions. The thickest observed CLEN lamellae are $\sim 0.4 \mu \mathrm{m}$. Clinoenstatites from Sulu have cell parameters: $a=9.67(7) \AA$, $b=8.88(6) \AA, c=5.22(3) \AA, \beta=107.7(2)^{\circ}$, and $V=427(8) \AA^{3}$, and those from Dabie: $a=9.53(6) \AA$, $b=8.88(6) \AA, c=5.24(3) \AA, \beta=107.0(2)^{\circ}$, and $V=424(8) \AA^{3}$. The TEM electron-diffraction patterns indicate that both clinoenstatites possess $P 2_{1} / c$ structures and are the low- $P$ polymorph of clinoenstatite. The host orthoenstatites have cell dimension: $a=18.32(12) \AA, b=8.88(6) \AA, c=$ 5.20(3) $\AA$ for the Sulu sample, and $a=18.24$ (12) $\AA, b=8.88$ (6) $\AA, c=5.18(3) \AA$ for the Dabie sample. Clinoenstatites in garnet pyroxenites from the Dabie-Sulu UHP terrane may have formed either by inversion from OREN, or by the displacive transformation from high- $P$ clinoenstatite during decompression.
\end{abstract}

\section{INTRODUCTION}

Pyroxenes are major constituents in mineralogical models of the Earth's upper mantle (Ringwood 1975). Five polymorphs of $(\mathrm{MgFe})_{2} \mathrm{Si}_{2} \mathrm{O}_{6}$ pyroxene are known: orthoenstatite (OREN, space group $P b c a)$, protoenstatite $(P b c n)$, low- $P$ clinoenstatite (LCLEN, $P 2_{1} / c$ ), high- $T$ clinoenstatite $(C 2 / c)$, and high- $P$ clinoenstatite (HCLEN, $C 2 / c$ ). Clinoenstatites occur mainly in meteorites; only trace amounts of clinoenstatite occur in volcanic rocks (Dallwitz et al. 1966; Komatsu 1980; Sameshima et al. 1983) and in amphibolite facies meta-peridotite (Trommsdorff and Wenk 1968; Katzir et al. 1999). The transformation from the orthorhombic to the monoclinic polymorph of pyroxene has been attributed to shear stress (e.g., Coe and Muller 1973). Some volcanic clinoenstatites have been interpreted as inverted from primary protoenstatite (Dallwitz et al. 1966; Nakamura 1971; Mori 1978). In these studies, high- $P$ and low- $P$ clinoenstatites have not been distinguished.

Orthoenstatite has long been considered to be stable in the upper mantle. However, recent experiments indicated that $\mathrm{Mg}$ end-member orthoenstatite transforms to high- $P$ clinoenstatite $(C 2 / c)$ at $P-T$ conditions ( $>8 \mathrm{GPa}, 900{ }^{\circ} \mathrm{C}$ ) corresponding to a depth of $\sim 300 \mathrm{~km}$ within the Earth's upper mantle (Gasparik 1990; Pacalo and Gasparik 1990; Angel et al. 1992; Hugh-Jones et al. 1994; Woodland and Angel 1997; Shinmei et al. 1999;

*E-mail: zhang@pangea.stanford.edu
Ulmer and Stalder 2000; Angel et al. 2000). Such transformation has been correlated with the "X seismic discontinuity" (Revenaugh and Jordan 1991; Woodland and Angel 1997).

Garnet peridotites and pyroxenites are common in UHP metamorphic terranes (Medaris 1999). The estimated peak pressures of rocks from the Dabie-Sulu UHP terrane are up to 6.7 $\mathrm{GPa}$ at $750-900{ }^{\circ} \mathrm{C}$ (Yang et al. 1993; Liou and Zhang 1998; Zhang et al. 1995, 2000) suggesting that they recrystallized at depths of $>200 \mathrm{~km}$ during subduction and continental collision. These petrologic data together with the above-mentioned experiments have led to questions such as: Did the high- $P$ clinoenstatite polymorph recrystallize in UHP garnet peridotite and pyroxenite at such depths? If so, how can we recognize the non-quenchable relict polymorph? Can the study of enstatite polymorphs provide new information for the process of continental subduction and mantle dynamics? An example of new information is the finding of low- $P$ clinoenstatite $\left(P 2_{1} / c\right)$ as exsolution lamellae in diopside from the Alpe Arami garnet peridotite, and it has been considered to have transformed from high- $P$ clinoenstatite $(C 2 / c)$ (Bozhilov et al. 1999).

A high concentration of exsolved clinopyroxene, rutile, and apatite in eclogitic garnet from the Sulu UHP terrane suggest UHP metamorphism at depths greater than $200 \mathrm{~km}$ (Ye et al. 2000). We have recently found that clinoenstatite is common in garnet pyroxenite and peridotite in this terrane. The present study reports our new observations and a TEM study of intergrowths of clinoenstatite and orthoenstatite in UHP gar- 
net pyroxenites from the Dabie-Sulu terrane, and discusses their possible origins.

\section{SAMPLE DESCRIPTION}

Coesite-bearing eclogites and garnet peridotites are widespread but volumetrically minor constituents in the Dabie-Sulu UHP terrane (Liou et al. 1996). These rocks developed during Triassic UHP metamorphism accompanying subduction and collision between the Sino-Korean and Yangtze craton (Li et al. 1993; Ames et al. 1996; Hacker et al. 1998, 2000). The garnet pyroxenites studied were collected from the Maowu layered pyroxenite body of the Dabie UHP belt, and from a core sample drilled in the Donghai area of the Sulu UHP belt. The $550 \mathrm{~m}$ drill cores consist mainly of gneiss $(0-28 \mathrm{~m})$, eclogite $(29-510 \mathrm{~m})$, and garnet peridotite at the bottom $(510-550 \mathrm{~m})$ (Z. Zhang et al. 2000). The rock studied by TEM is only about $1 \mathrm{~m}$ thick at the $465 \mathrm{~m}$ level and occurs within coesite-bearing eclogites.

\section{Donghai garnet pyroxenite}

The garnet pyroxenite from Donghai core $(95 \mathrm{M} 1 \mathrm{H})$ is coarsely granoblastic and consists of about $40 \%$ titanomagnetite, $30 \%$ enstatite, $20 \%$ garnet $\left(\operatorname{Prp}_{54} \mathrm{Alm}_{37} \mathrm{Grs}_{6} \mathrm{Sps}_{3}\right)$, and $10 \%$ magnesite $[\mathrm{Mg} /(\mathrm{Fe}+\mathrm{Mg})=0.91]$. These phases show equilibrium triple-junction contacts and have homogeneous compositions. Both garnet and enstatite contain abundant discrete inclusions of ilmenite and exhibit rods of exsolved apatite. Most ilmenite inclusions are unoriented, rounded grains $\sim 0.02-0.3 \mathrm{~mm}$ across, although a few ilmenite inclusions are elongated rods. Enstatites contain $80 \pm 5 \mathrm{~mol} \% \mathrm{MgSiO}_{3}$ and 0.16 wt $\% \mathrm{Al}_{2} \mathrm{O}_{3}$ (Table 1). Titanomagnetite occurs as interstitial grains between other phases and shows abundant ilmenite and hematite lamellae resulting from oxidation-exsolution; the ilmenite ranges from several to tens of micrometers in width and has variable length. Coexistence of magnetite and ilmenite suggests the rock reequilibrated at about $700{ }^{\circ} \mathrm{C}$ (Buddington and Lindsley 1964), or at $760{ }^{\circ} \mathrm{C}$ at oxygen fugacities slightly above the quartzmagnetite-fayalite buffer (Andersen and Lindsley 1988).

\section{Maowu garnet pyroxenite}

The Maowu mafic-ultramafic body is tectonically enclosed within garnet-bearing UHP gneisses, and consists of layered harzburgite, orthopyroxenite, clinopyroxenite, and minor coesite-bearing omphacitite and eclogite (Liou and Zhang 1998; Zhang et al. 2000). The occurrence of coesite inclusions and $P$ - $T$ estimates of various rocks indicate that the Maowu ultramafic body was subjected to UHP metamorphism at about 4.0 $6.7 \mathrm{GPa}$ and $\sim 750^{\circ} \mathrm{C}$ (Okay 1994; Liou and Zhang 1998; Zhang et al. 1999).

Orthopyroxenites from the Maowu body consist of garnet + enstatite \pm clinohumite \pm magnesite. Sample $55 \mathrm{C}$ was selected for detailed TEM examination as it contains abundant clinoenstatite lamellae in elongated coarse-grained $(1-6 \mathrm{~mm})$ enstatite. Garnet is Cr-bearing pyrope $\left(\mathrm{Cr}_{2} \mathrm{O}_{3}, 0.25-1.87 \mathrm{wt} \%\right.$, $\left.\operatorname{Prp}_{73}\right)$. Enstatite $\left(\mathrm{En}_{92}\right)$ has a very low $\mathrm{Al}_{2} \mathrm{O}_{3}$ content $(0.08-0.19$ wt\%) (Table 1). The above $P$-T estimates are consistent with the very low $\mathrm{Al}$ content in orthopyroxene and the high $\mathrm{Cr}_{2} \mathrm{O}_{3}$ content of pyropic garnet.
The orthopyroxenes in both Maowu and Donghai samples exhibit clinoenstatite lamellae with a maximum thickness of about $1 \mu \mathrm{m}$ and length up to hundreds of $\mu \mathrm{m}$, and are nearly $\mathrm{Ca}$-free. The clinoenstatite lamellae can be seen by optical microscopy in some enstatite grains (Fig. 1). Some optically homogeneous pyroxenes $\left[(\mathrm{Mg}, \mathrm{Fe}) \mathrm{SiO}_{3}\right]$ have extinction angles of $5-25^{\circ}$. However, in some grains that contain intergrowths of orthoenstatite and clinoenstatite, only the clinoenstatite lamellae rather than the whole crystal exhibit inclined extinction (Fig. 1b).

\section{ANALYTICAL TECHNIQUES AND RESULTS OF TRANS- MISSION ELECTRON MICROSCOPY (TEM)}

To characterize the very fine lamellae within the enstatite grains, and to determine the cause of inclined extinction for Cafree "enstatite" crystals in garnet pyroxenites from the DabieSulu terrane, several crystals were examined using a JEOL 3010 scanning transmission electron microscope (operated at $300 \mathrm{kV}$ )
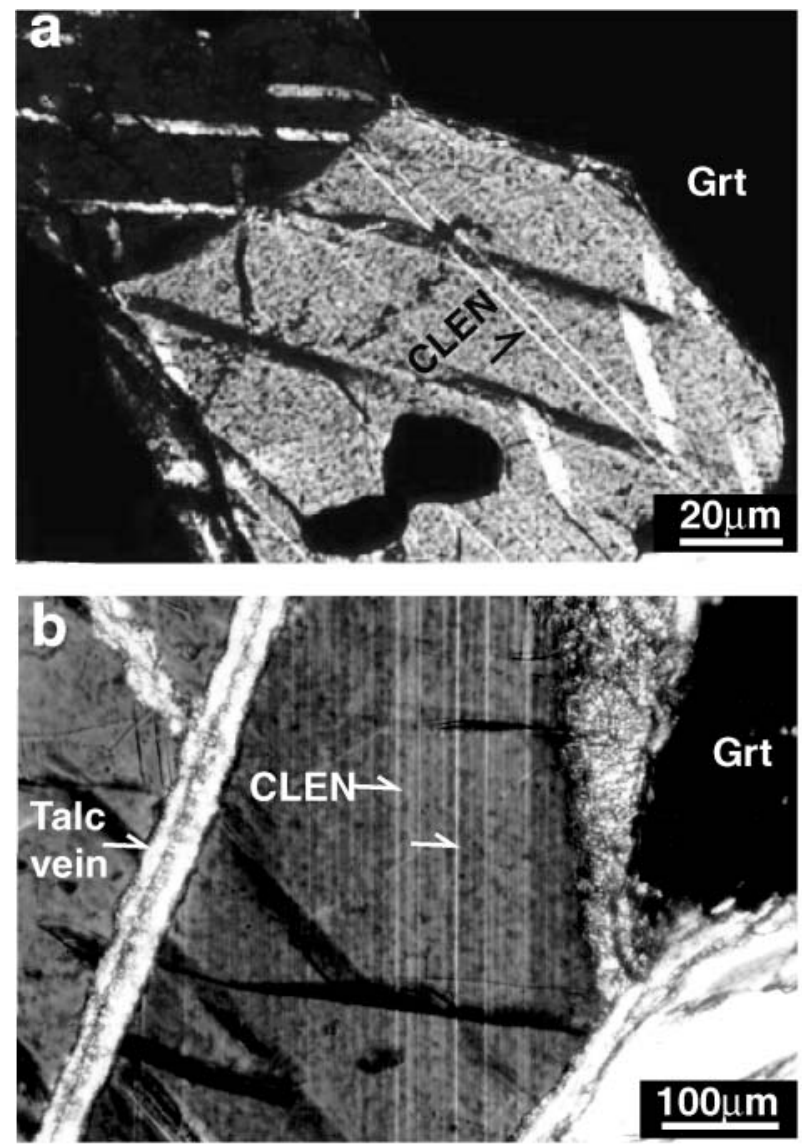

FIGURE 1. Photomicrographs (crossed polarizers) showing mineral assemblages and optically visible clinoenstatite. (a) Enstatite grains (Donghai sample) with very thin clinoenstatite lamellae. Two sets of discontinuous microfractures (one set black and the other set white) intersect at approximately $127^{\circ}$ and are filled with calcite. (b) Clinoenstatite lamellae (parallel to the NS crosshair indicated by arrow) show inclined extinction, in contrast to the majority of the crystals that are orthoenstatite with parallel extinction. 
TABLE 1. Mineral compositions of garnet pyroxenites from Dabie-Sulu UHP terrane

\begin{tabular}{|c|c|c|c|c|c|c|c|c|c|c|c|c|c|c|}
\hline \multirow{2}{*}{$\begin{array}{l}\text { Location } \\
\text { Mineral }\end{array}$} & \multicolumn{10}{|c|}{ Donghai } & \multicolumn{4}{|c|}{ Maowu } \\
\hline & En & OREN $^{*}$ & CLEN $^{*}$ & Grt & Mgs & Mag & $\mathrm{IIm}$ & Grt-c & En-c & Grt-r & En & OREN $^{*}$ & OREN $^{*}$ & CLEN $^{*}$ \\
\hline $\mathrm{SiO}_{2}$ & 56.93 & 59.97 & 59.85 & 40.65 & 0.00 & 0.00 & 0.00 & 42.33 & 58.77 & 42.77 & 59.73 & 59.33 & 59.48 & 59.73 \\
\hline $\mathrm{TiO}_{2}$ & 0.02 & 0.28 & 0.26 & 0.12 & 0.00 & 16.33 & 47.14 & 0.02 & 0.00 & 0.00 & 0.00 & 0.00 & 0.00 & 0.06 \\
\hline $\mathrm{Cr}_{2} \mathrm{O}_{3}$ & 0.00 & n.d. & n.d. & 0.00 & 0.00 & 0.09 & 0.00 & 1.87 & 0.02 & 1.40 & 0.01 & n.d. & n.d. & n.d. \\
\hline $\mathrm{Al}_{2} \mathrm{O}_{3}$ & 0.17 & 0.15 & 0.11 & 22.94 & 0.00 & 0.09 & 0.01 & 22.37 & 0.08 & 22.65 & 0.15 & 0.00 & 0.00 & 0.00 \\
\hline $\mathrm{FeO}$ & 10.20 & 14.63 & 13.67 & 18.48 & 7.07 & 82.33 & 46.91 & 11.89 & 5.51 & 12.15 & 5.03 & 4.85 & 4.26 & 4.52 \\
\hline $\mathrm{MnO}$ & 0.33 & 0.04 & 0.59 & 1.77 & 0.28 & 0.07 & 0.20 & 0.49 & 0.02 & 0.42 & 0.04 & 0.08 & 0.05 & 0.14 \\
\hline $\mathrm{MgO}$ & 32.20 & 24.47 & 25.41 & 14.43 & 38.12 & 0.59 & 2.72 & 20.41 & 36.23 & 20.64 & 36.37 & 35.67 & 36.05 & 35.55 \\
\hline $\mathrm{CaO}$ & 0.08 & 0.10 & 0.11 & 2.32 & 0.12 & 0.00 & 0.00 & 1.69 & 0.07 & 1.43 & 0.02 & 0.07 & 0.15 & 0.01 \\
\hline $\mathrm{Na}_{2} \mathrm{O}$ & 0.03 & n.d. & n.d. & 0.00 & 0.02 & 0.02 & 0.01 & 0.03 & 0.02 & 0.00 & 0.02 & n.d. & n.d. & n.d. \\
\hline Total & 99.95 & 100.00 & 100.00 & 100.71 & 45.61 & 99.52 & 96.99 & 101.43 & 100.72 & 101.46 & 101.37 & 100.00 & 100.00 & 100.00 \\
\hline
\end{tabular}

\begin{tabular}{|c|c|c|c|c|c|c|c|c|c|c|c|c|c|c|}
\hline \multicolumn{15}{|c|}{ Formula proportions of cations } \\
\hline $\mathrm{Si}$ & 1.996 & 2.12 & 2.11 & 2.993 & 0.000 & 0.000 & 0.000 & 3.004 & 1.999 & 3.019 & 2.011 & 2.02 & 2.02 & 2.03 \\
\hline $\mathrm{Ti}$ & 0.000 & 0.01 & 0.01 & 0.007 & 0.000 & 0.432 & 0.930 & 0.001 & 0.000 & 0.000 & 0.000 & 0.00 & 0.00 & 0.00 \\
\hline $\mathrm{Cr}$ & 0.000 & 0.00 & 0.00 & 0.000 & 0.000 & 0.003 & 0.000 & 0.105 & 0.001 & 0.078 & 0.000 & & & \\
\hline $\mathrm{Al}$ & 0.007 & 0.01 & 0.00 & 1.991 & 0.000 & 0.004 & 0.000 & 1.871 & 0.003 & 1.884 & 0.006 & 0.00 & 0.00 & 0.00 \\
\hline $\mathrm{Fe}$ & 0.299 & 0.43 & 0.40 & 1.138 & 0.094 & 1.568 & 1.029 & 0.706 & 0.157 & 0.717 & 0.142 & 0.14 & 0.12 & 0.13 \\
\hline $\mathrm{Mn}$ & 0.010 & 0.00 & 0.02 & 0.110 & 0.004 & 0.002 & 0.004 & 0.029 & 0.001 & 0.020 & 0.001 & 0.00 & 0.00 & 0.00 \\
\hline $\mathrm{Mg}$ & 1.683 & 1.29 & 1.34 & 1.584 & 0.900 & 0.031 & 0.106 & 2.159 & 1.837 & 2.172 & 1.825 & 1.81 & 1.83 & 1.80 \\
\hline $\mathrm{Ca}$ & 0.003 & 0.00 & 0.00 & 0.183 & 0.002 & 0.000 & 0.000 & 0.129 & 0.003 & 0.108 & 0.001 & 0.00 & 0.01 & 0.00 \\
\hline & 0.002 & 0.00 & 0.00 & 0.000 & 0.001 & 0.001 & 0.001 & 0.004 & 0.001 & 0.003 & 0.001 & & & \\
\hline Total & 4.001 & 3.87 & 3.88 & 8.005 & 1.000 & 2.041 & 2.070 & 8.009 & 4.000 & 8.001 & 3.987 & 3.97 & 3.98 & 3.96 \\
\hline
\end{tabular}

Notes: $\mathrm{C}=$ core; $\mathrm{r}=$ rim. Mineral abbreviations: $\mathrm{En}=$ enstatite; $\mathrm{CLEN}=$ clinoenstatite; OREN = orthoenstatite; Grt = garnet; Ilm = ilmenite; Mag = magnetite; Mgs = magnesite.

* TEM semi-quantitative energy dispersive spectrometric (AEM) analysis, oxides are normalized to total 100 wt\%; others are electron microprobe analysis.

equipped with a Link systems energy dispersive spectrometer (EDS). Lattice-fringe images and selected-area electron diffraction (SAED) patterns were collected and cell dimensions and compositions of the crystals were determined. The TEM specimens were prepared from polished rock thin sections, which were mounted using thermo-sensitive cement (Lakeside 70). Enstatite grains showing very thin lamellae with sharp boundaries, or basal sections with symmetrical extinction, were chosen for TEM study, as the (100) or the $c$-axis, respectively, of these crystals are nearly perpendicular to the grain surface. The specimens were ion thinned using a Gatan 600 DuoMill. The EDS data in Table 1 are denoted as AEM (analytical electron microscopic) analyses, and were obtained in transmission mode using an electron beam approximately $100 \AA$ in diameter. Experimentally determined $k$ values (Cliff-Lorimer factors) for $\mathrm{Ca}, \mathrm{Ti}$, and $\mathrm{Fe}$ (using standards of natural wollastonite, synthetic Ti metal, and iron silicide, $\mathrm{FeSi}_{2}$, respectively), and factory preset $k$ values (Link Virtual Standard Pack) for Si, Al, $\mathrm{Mn}$, and $\mathrm{Mg}$ were used to obtain these semi-quantitative compositional data (Cliff and Lorimer 1975).

TEM examination reveals coherent intergrowths of clinoenstatite and orthoenstatite. Several examples are described in detail below. The CLEN lamellae in the OREN for both Donghai and Maowu samples have the same orientation. The Maowu enstatites contain much more abundant CLEN; a single lamellar zone can be as large as $\sim 0.36 \mu \mathrm{m}$ in thickness. For the Donghai sample, clinoenstatite lamellae constitute up to $22 \mathrm{vol} \%$ in an area of $5000 \times 3850 \AA$. Clinoenstatite lamellae and orthoenstatite host in both samples have nearly identical compositions as revealed by semi-quantitative AEM analyses (Table 1).

\section{Donghai clinoenstatite}

The CLEN lamellae are sparsely distributed and oriented parallel to (100) of enstatite. The intergrowth texture can be clearly seen on the grains of $a-c$ sections. A few lamellae are very closely spaced and have a combined width of $0.2 \mu \mathrm{m}$, which can just be resolved by the polarizing microscope. But most lamellae range from tens to hundreds of $\AA$ in width. The lamellae consist of $9 \AA$ fringes of CLEN as shown in the highresolution images. The OREN host shows a periodicity of $18 \AA$ along [100]. In addition to the majority of the $18 \AA$ for OREN and $9 \AA$ lamellae for CLEN, periodicities of 36 and $72 \AA$ are also observed (Fig. 2). All the observed CLEN lamellae enclosed in the OREN host are composed of even number (e.g., 2, 4, 6, 8, 16, and 72) $9 \AA$ fringes. The packets of CLEN fringes display identical contrast indicating that they are in the same orientation with no twinning relationship.

Two [010] selected-area electron diffraction patterns for the Donghai sample are shown in Figure 3; one illustrates both clinoenstatite and orthoenstatite, and the other shows orthoenstatite alone $\left(d_{100}=18 \AA\right.$ for OREN and $d_{100}=9 \AA$ for

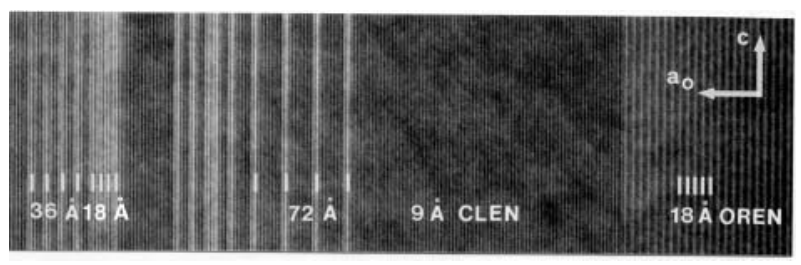

Figure 2. A [010] TEM image of the Donghai sample showing lattice fringes parallel to (100) of the CLEN lamellae and OREN host. The CLEN and OREN show 9 and $18 \AA$ periodicities, respectively. Periodicities of $36 \AA$ (1 OREN layer +2 CLEN layers) and $72 \AA$ (1 OREN layer +6 CLEN layers) are also observed. The thickest CLEN packet (middle part of the figure) contains 72 layers of $9 \AA$ fringes. Other CLEN lamellae are of 2, 4, and 14 layers. The $c$-axis (c) of both OREN and CLEN, and the $a$-axis of OREN (a) are indicated on the photograph. 
CLEN). In the [010] patterns, the $h 0 l$ reflections with $l=2 n+$ 1 are absent. This fact indicates the presence of a $c$-glide parallel to (010) for both OREN and CLEN. Reflections occur for all values of $h$, but the $h 0 l$ reflections with $h=2 n$ have much stronger intensity than those with $h=2 n+1$ for CLEN. In the [011] zone patterns, the presence of reflections with $h+k=2 n$ +1 (such as 100 or 011) for CLEN violates the systematic absences for a $C$ cell, and indicates a primitive space group $\left(P 2_{1} / c\right)$ for the CLEN. In the [001] diffraction pattern, the $h k 0$ reflections with $h=2 n+1$ for OREN are absent, indicating an $a$-glide perpendicular to the $c$-axis, and the $0 k 0$ reflections with $k=2 n+1$ are also extinct, which is consistent with a $b$-glide perpendicular to the $a$-axis for the OREN. The differences of intensity for the reflections on $a^{*}-c^{*}, a^{*}-b *$ sections and other orientations appear to be consistent with space groups $\mathrm{Pbca}$ for the OREN and $P 2_{1} / c$ for the CLEN. The measured unit-cell parameters of OREN and CLEN, as derived from the electron diffraction patterns, are listed in Table 2.

\section{Maowu clinoenstatite}

The enstatites of the Maowu pyroxenite sample display much more abundant, more readily distinguishable lamellar textures than those in the Donghai sample, and this difference is apparent with optical observation. The TEM images show that these enstatites consist of intimately intergrown CLEN and OREN lamellae along (100). However, the abundance of CLEN lamellae and their thickness vary from grain to grain. Within some grains, the CLEN may be up to $50 \mathrm{vol} \%$, as observed in areas extending several micrometers along the $a$ axis of the OREN. Figure 4 shows a lamellar texture composed of intercalated, very fine OREN and CLEN lamellae. The boundaries
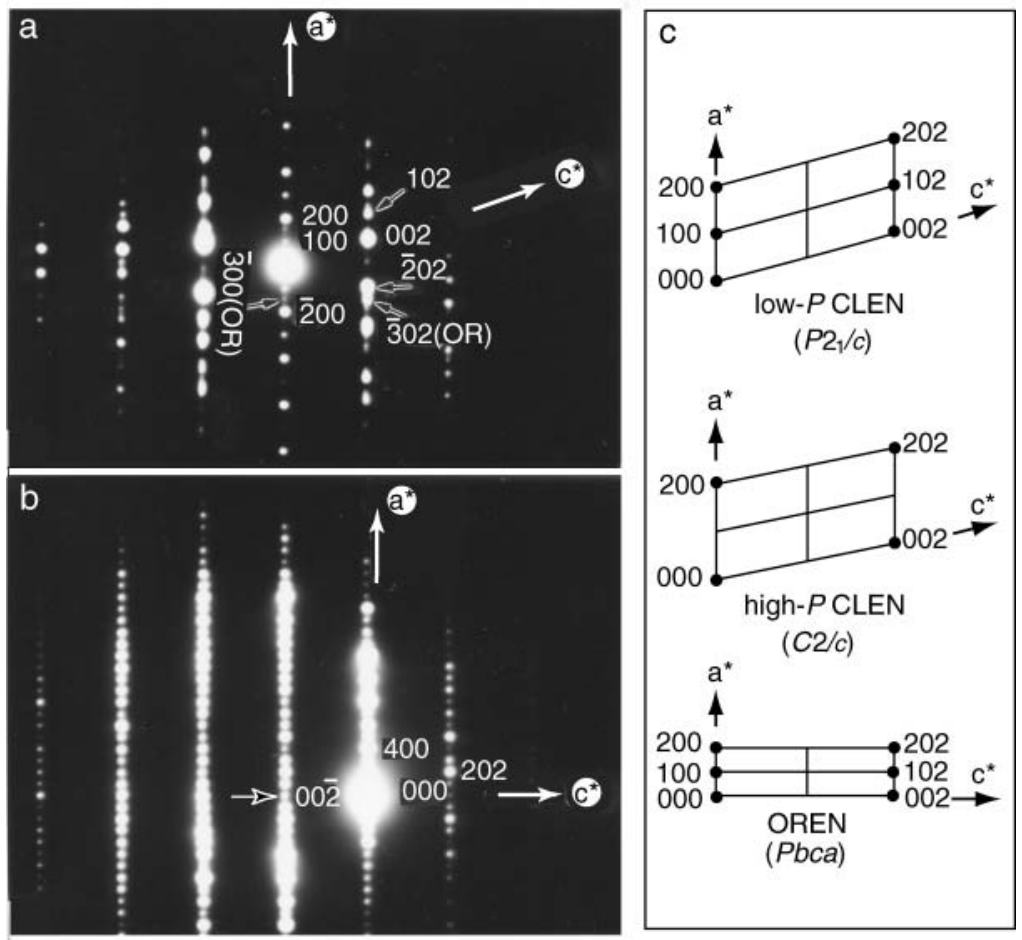

TABLE 2. Unit-cell parameters for the OREN and CLEN from garnet pyroxenites

\begin{tabular}{|c|c|c|c|c|}
\hline \multirow[b]{2}{*}{ Space group } & \multicolumn{2}{|c|}{ Maowu } & \multicolumn{2}{|c|}{ Donghai } \\
\hline & Pbca & $P 2_{1} / \mathrm{C}$ & Pbca & $P 2_{1} / \mathrm{C}$ \\
\hline$a(\AA ̊)$ & $18.24(12)^{*}$ & $9.53(6)$ & $18.32(12)$ & $9.67(6)$ \\
\hline$b(\AA)$ & $8.88(6)$ & $8.88(6)$ & $8.88(6)$ & $8.88(6)$ \\
\hline$c(\AA)$ & $5.18(3)$ & $5.24(3)$ & $5.20(3)$ & $5.22(3)$ \\
\hline$\beta$ & $90^{\circ}$ & $107.0(2)^{\circ}$ & $90^{\circ}$ & $107.7(2)^{\circ}$ \\
\hline$V\left(\AA^{3}\right)$ & $839(17)$ & $424(8)$ & $846(17)$ & $427(8)$ \\
\hline$V\left(\mathrm{~cm}^{3} / \mathrm{mol}\right)$ & $31.6(6)$ & $31.9(6)$ & $31.8(6)$ & $32.2(6)$ \\
\hline
\end{tabular}

* Values in parentheses are estimated errors in the last decimal number; these errors occur in making measurements of electron diffraction photographs. Camera constants of the TEM for determination of lattice spacings were calibrated using evaporated aluminum film as diffraction standard.

between the OREN and CLEN do not show strain contrast and appear to be coherent. A high-resolution image (Fig. 5) for the same grain shows intimate intergrowths of lamellae of OREN [(100) lattice fringes with $18 \AA$ A repeats] and CLEN [(100) lattice fringes with $9 \AA$ repeats]. The $(02 \overline{1})$ lattice fringes with $3.3 \AA$ repeats for OREN are perpendicular to (100) of the OREN. The continuous layers (18 ̊ wide fringes) for each single OREN lamella range from one to about ten $18 \AA$ Alayers, whereas those for CLEN lamellae are similar, but always with an even number of $9 \AA$ layers. All the CLEN lamellae show identical contrast indicating that they are in the same orientation. Some pyroxene grains contain CLEN lamellae that are up to $0.36 \mu \mathrm{m}$ thick. The thick CLEN lamellae are interrupted by OREN of one or a few layers.

Figures $6 \mathrm{a}$ and $6 \mathrm{~b}$ are SAED patterns for the OREN and CLEN, respectively. The streaks parallel to $a^{*}$ of the OREN SAED pattern (Fig. 6a) are caused by intimate intergrowth of very fine CLEN lamellae on (100) of the OREN. Some weak reflections of the CLEN can be seen along non- $h 00$ reflection rows, such as $h 2 \overline{1}, h 4 \overline{2}$, or $h 6 \overline{3}$ rows (Fig. 6a). All $h$ odd reflections (e.g., 100, 12 $\overline{1}$, and $14 \overline{2}, h$ $+k=2 n+1)$ are present for the CLEN in this [012] zone pattern and are thus consistent with a primitive lattice $\left(P 2_{1} / c\right)$ rather than a $C$ lattice for the CLEN in the Maowu sample.

\section{DISCUSSION}

Formation of the CLEN lamellae in OREN is different from an exsolution process involving a solid solution, whereby an initially homogenous solid-solution phase

Figure 3. [010] SAED patterns for the CLEN lamellae (a) and OREN host (b) that are shown in Figure 2. (a) The reflections obtained from the thickest CLEN lamella show an oblique reciprocal lattice that displays of 000, 100, 102, and 002 reflections. Weak reflections of 300 and $\overline{3} 00$ for OREN also can be seen. (b) SAED pattern from the OREN showing a rectangular reciprocal lattice with $d_{100}=18 \AA$ (Donghai sample). (c) Outlines with reflection spots for the CLEN and OREN reciprocal lattices. 


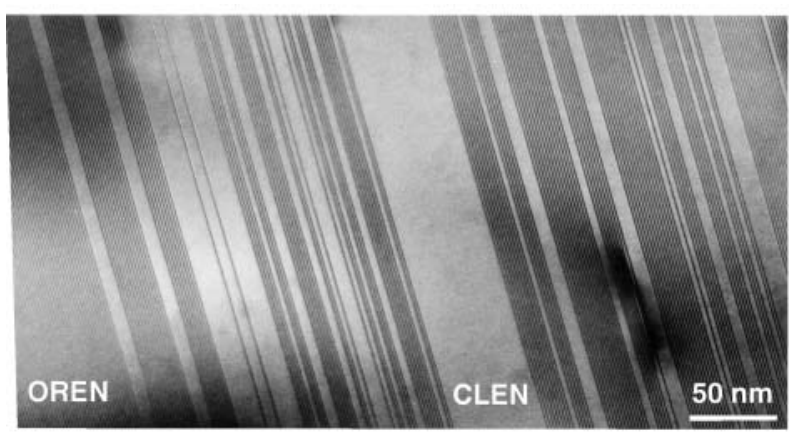

Figure 4. [012] TEM image of the Maowu sample showing intimate intergrowth of OREN (darker contrast with $18 \AA$ fringes, $d_{100}$ ) and CLEN (lighter contrast with $9 \AA$ fringes). The CLEN lamellae have the same contrast within every lamella, indicating that they are in the same orientation (without twins). Some OREN lamellae are only one layer $(18 \AA)$ thick. The thickest CLEN lamellae in this image are about $0.06 \mu \mathrm{m}$ thick.

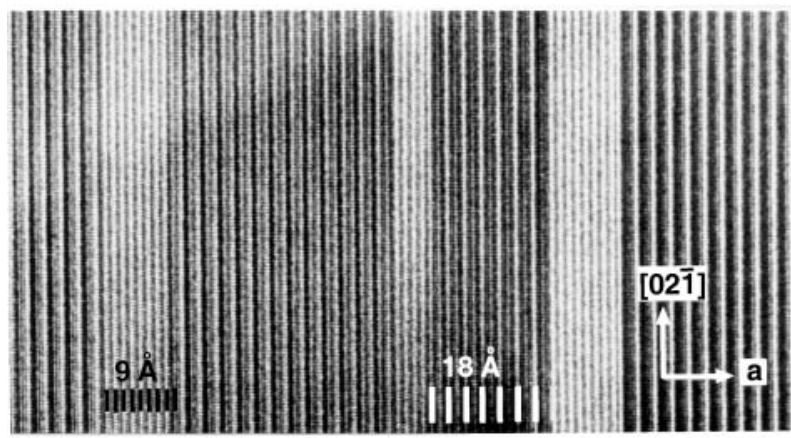

FigURE 5. A high-magnification electron micrograph of Maowu sample (55C) showing OREN and CLEN lamellae containing 18 and 9 $\AA$ (100) fringes respectively. Another set of fringes perpendicular to (100) of OREN and with a $3.3 \AA$ repeat is representative of $(02 \overline{1})$ of OREN. The [012] of OREN is parallel to the electron beam. Two arrows indicate $a$ and $[02 \overline{1}]$ of OREN.

separates into two compositionally distinct phases during cooling. The LCLEN $\left(P 2_{1} / c\right)$ lamellae in the studied enstatite grains have nearly identical chemical compositions to the OREN matrix $(P b c a)$. The lamellar textures thus can be treated as different polytypes of enstatite, with $9,18,36$, and $72 \AA$ periodicities, although Buseck and Iijima (1975) only found 27,36 , and $54 \AA$ repeats in meteorites. Among the five polymorphs of $\mathrm{MgSiO}_{3}$, protoenstatite $(P b c n)$ and high- $T$ clinoenstatite $(C 2 / c)$ have restricted stability fields at $P<1$ GPa and $1000-1500{ }^{\circ} \mathrm{C}$ and $T>1500{ }^{\circ} \mathrm{C}$, respectively (Pacalo and Gasparik 1990); these $P-T$ conditions can be ruled out for discussion of these UHP rocks. Based on petrologic information and TEM analyses, the clinoenstatite $\left(P 2_{1} / c\right)$ lamellae within orthoenstatite $(\mathrm{Pbca}$ ) may have formed by either of two mechanisms: (1) transformation from orthoenstatite due to shearing or slow cooling; or (2) inversion from high- $P$ clinoenstatite during decompression. These possibilities are discussed below:
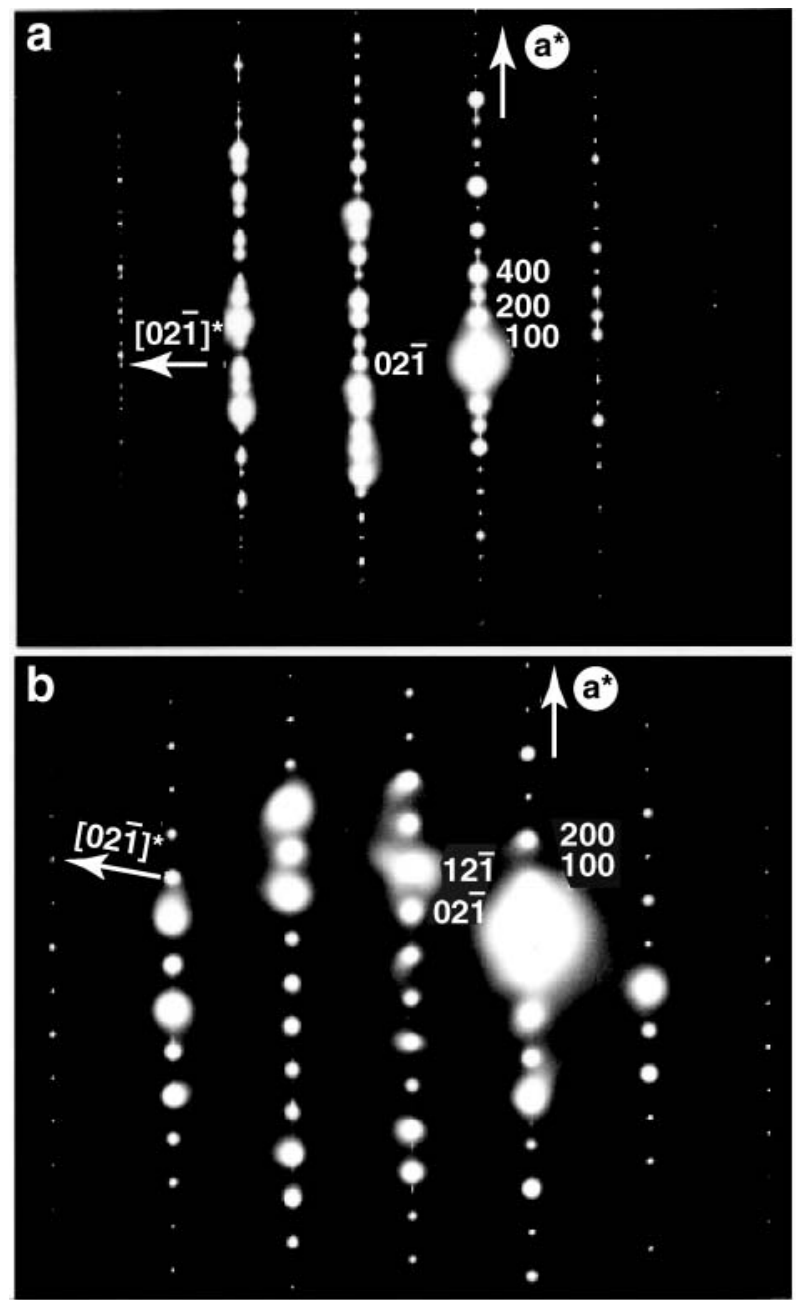

FIGURE 6. [012] SAED patterns for the lamellae of OREN (a) and CLEN (b) that are shown in Figure 4. (a) A [012] SAED pattern taken from the OREN area, which is mixed with very thin CLEN lamellae. (b) A [012] SAED pattern taken from the thickest CLEN lamella (0.36 $\mu \mathrm{m})$ that shows no OREN layers.

\section{(1) Clinoenstatite formed by transformation of ortho-} enstatite at a retrograde stage due to gentle shearing or slow cooling

The ways of stacking pyroxene layers are referred to as "stacking sequences" (Papike et al. 1973); Buseck et al. (1980) further abstracted the pyroxene structure types into blocks of $4.5 \AA$ wide normal to (100). For CLEN, all of the blocks have same orientation, and can be represented either as (++++) or as ( $-\ldots \ldots$ - ) depending on the orientation of the blocks with respect to the unit-cell axes. The stacking sequence of the OREN structure is $(++--++--)$. The transformation of enstatite $\left(\mathrm{MgSiO}_{3}\right)$ from the OREN to the CLEN polymorph requires rearrangement of the octahedral sequence so as to change (-) stacking to (++) stacking or the opposite. In the 1960s and 1970s, this type of transition was thought to be caused by shock, or gradual and long-sustained directed stresses, or by static transformation from OREN (e.g., Buseck et al. 1980). In most cases, the transformation in terrestrial rocks has been attrib- 
uted to shear stress on (100) planes in the [100] direction (Coe and Muller 1973; Smyth 1974; McLaren and Etheridge 1976); this transformation model requires either a $13.3^{\circ}$ (Coe and Muller 1973; Coe and Kirby 1975) or an $18.3^{\circ}$ shear (Turner et al. 1960). From TEM studies of several terrestrial and meteoritic enstatites, Buseck and Iijima (1975) proposed that the formation path of the CLEN from OREN is related to the following factors: (1) the CLEN field width within the OREN matrix in terms of $(2 n+1) 9 \AA$ or $(2 n) 9 \AA$, where $n$ is an integer number; (2) the presence of twinning; and (3) the concentration of the CLEN lamellae in the OREN matrix (see Table 1 of Buseck and Iijima 1975). The clinoenstatite transformed from protoenstatite would have the CLEN field widths of both $(2 n+$ 1) $9 \AA$ and $(2 n) 9 \AA$, and would be twinned owing to random nucleation. If the inversion is due to static transformation or inhomogeneous shear (or shock), the resulting CLEN is characterized by development of abundant stacking faults and twins. In the present study, antiphase domain boundaries resulting from the transformation of low- $P$ CLEN $\left(P 2_{1} / c\right)$ from high- $P$ CLEN $(C 2 / c)$ have not been observed by dark-field imaging. All the observed CLEN lamellae, as shown in the TEM images of Figures 2, 4, and 5 for the Sulu and Dabie garnet pyroxenites are composed of $2 n 9 \AA$ layers and formed at high $P / T$ condition. These characteristics imply that the CLEN could have formed from transformation of OREN rather than from protoenstatite. The studied clinoenstatite lamellae have the same crystallographic orientations without twinning, suggesting that the transformation of CLEN from OREN could be due to homogeneous (or gentle) shearing (see Table 1, Buseck et al. 1980). The number of CLEN lamellae within OREN is much greater in the Maowu sample than in the Donghai sample. The abundance of CLEN lamellae in the Maowu sample seem to be consistent with an intense shear that resulted in more pronounced foliation for the Maowu garnet pyroxenite. The tectonic processes that caused the homogeneous shear stresses might have taken place during exhumation of the subducted slab.

Another possibility for low- $P$ enstatite formation is direct inversion from orthoenstatite due to slow cooling. The estimated equilibration temperature of $\sim 750{ }^{\circ} \mathrm{C}$ is very close to the orthopyroxene-low- $P$ clinopyroxene phase boundary at pressures of 4-6 GPa (Fig. 7). The transformation from OREN to low-P CLEN is very sluggish because of the small differences in the free energy of the two phases close to the phase boundary. However, if cooling was slow and there is a reasonable temperature overstep, OREN would be expected to invert to low- $P$ CLEN. The inversion process may lead to the development of multiple repeats of the lattice fringes as shown in Figures 2 and 4 and produce few or no twins.

\section{(2) An open question: does the clinoenstatite formed by inversion of high- $P$ clinoenstatite?}

Clinoenstatite lamellae as thick as $\sim 0.36$ and $\sim 0.06 \mu \mathrm{m}$ in the Maowu and Donghai samples, respectively, have not been previously reported in natural OREN crystals. High- $P$ CLEN $(C 2 / c)$ is a non-quenchable phase and transforms to low- $P$ CLEN with space group $P 2_{1} / c$ during decompression at $P<7$ $\mathrm{GPa}$, based on experiments and single-crystal X-ray diffraction studies (e.g., Angel and Hugh-Jones 1994; Hugh-Jones et
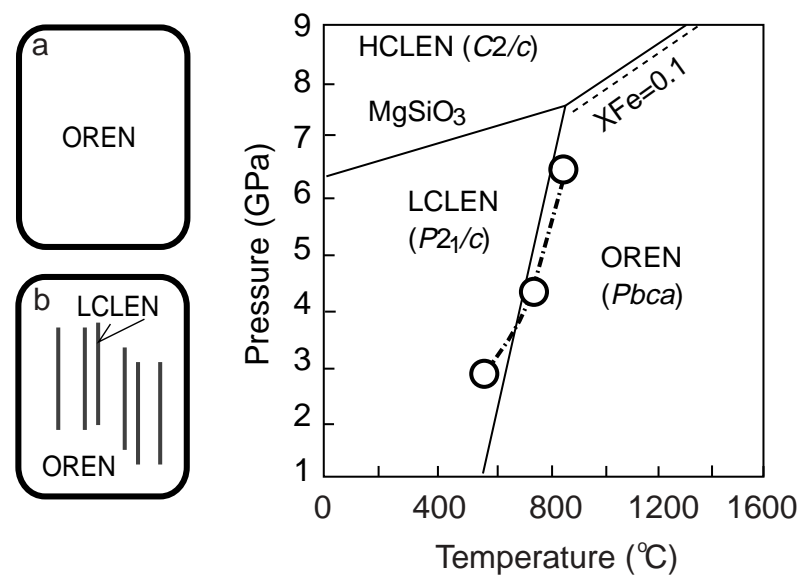

FIGURE 7. Schematic diagram illustrating the formation of the observed clinoenstatite lamellae by gentle shear or slow cooling. Phase relations for $\mathrm{MgSiO}_{3}$ and $\mathrm{FeSiO}_{3}$ after Woodland and Angel (1997, Fig. 3).

al. 1994; Ulmer and Stalder 2000). These results suggest that high- $P$ clinoenstatite cannot be preserved in natural rocks.

Petrologic data indirectly provide important constraints for a possible UHP origin of CLEN. Pyropic garnet and magnesite are important phases in the studied garnet pyroxenites, inasmuch as these phases are stable at deep mantle conditions. The highest $P$ estimates of about $6.7 \mathrm{GPa}$ at $750 \pm 50{ }^{\circ} \mathrm{C}$ are from the Grt-Opx pairs containing a very low $\mathrm{Al}_{2} \mathrm{O}_{3}$ content $(<0.10$ wt $\%$ ), and they are very close to the high- $P$ clinoenstatiteorthoenstatite phase boundary. Moreover, pressure estimates of the studied clinoenstatite-bearing samples may only record $P-T$ conditions of later stage recrystallization rather than actually peak pressure. The inferred pressures based on exsolution within high- $P$ phases are much higher than that obtained by thermobarometric methods (Bozhilov et al. 1999; Ven Roermund et al. 2000). The suggestion of UHP origin is also consistent with high $\mathrm{TiO}_{2}(0.12 \mathrm{wt} \%)$ in garnet from sample $95 \mathrm{M} 1 \mathrm{H}$ (Table 1), and the occurrence of rods of exsolved apatite in garnet indicating the coupled substitutions of ${ }^{\mathrm{VIII}}(\mathrm{Mg}, \mathrm{Fe}, \mathrm{Ca})+{ }^{\mathrm{VI}} \mathrm{Ti}=2{ }^{\mathrm{VI}} \mathrm{Al}$ and ${ }^{\mathrm{VIII}} \mathrm{Ca}+{ }^{\mathrm{IV}} \mathrm{Si}={ }^{\mathrm{VIII}} \mathrm{Na}+{ }^{\mathrm{IV}} \mathrm{P}$ at high pressures (Ringwood and Lovering 1970; Thompson 1975)

Other lines of evidence indicate that some Dabie-Sulu garnet peridotites may have originated from great mantle depths. Ye et al. (2000) reported high contents of clinopyroxene, rutile, and apatite exsolution in eclogitic garnets from the Sulu UHP belt, and suggested that high concentrations of calculated $\mathrm{Na}_{2} \mathrm{O}$ and octahedral $\mathrm{Si}$ in garnet resulted from UHP metamorphism at depths greater than $200 \mathrm{~km}$. They predicted that much largerscale, extremely deeply subducted crustal materials may occur in this belt. Such materials would be indicated by the presence of appropriate mineralogical or microtextural evidence-such as $\mathrm{TiO}_{2}$ with the $\alpha-\mathrm{PbO}_{2}$ structure (stable at $5-7 \mathrm{GPa}$ ), $\mathrm{K}$ wadeite (6.5-7 GPa), or high-pressure $C 2 / c$ clinoenstatite. We have also recently found abundant exsolution rods of garnet and ilmenite in coarse-grained clinopyroxenes from nearby garnet clinopyroxenite, and interpreted these as evidence for the former existence of Ti-rich majoritia garnet formed at $P>$ $9 \mathrm{GPa}$ (Zhang and Liou, unpublished manuscript). 
The most recent experimental data indicated that high- $P$ clinoenstatite is stable at pressures of $>6 \mathrm{GPa}$; three polymorphs (low- $P$ CLEN, high- $P$ CLEN, and OREN) coexist at an invariant point at $6.6 \mathrm{GPa}$ and $820^{\circ} \mathrm{C}$ (Ulmer and Stalder 2001). To consider phase relations involving OREN ( $P b c a)$, high- $P$ CLEN $(C 2 / c)$, and low- $P$ CLEN $\left(P 2_{1} / c\right)$ for $\mathrm{MgSiO}_{3}$ end-member and a possible higher peak temperature of $\geq 800{ }^{\circ} \mathrm{C}$, the observed intergrowth of OREN and low-P CLEN in the DabieSulu UHP rocks could have formed at pressures greater than 6 $\mathrm{GPa}$ at $800^{\circ} \mathrm{C}$ (Fig. 7). Similar $P$-T estimates of $800-950{ }^{\circ} \mathrm{C}$ and 4-6.7 GPa have been obtained for the recrystallization of nearby garnet peridotites (Yang et al. 1993; Zhang et al. 1995, 2000), which lies very close to the triple point of Figure 7.

Antiphase domains were not observed within the clinoenstatite lamellae in the two samples that were studied. However, the $h 0 l$ reflections with $h=2 n$ have much stronger intensities than those with $h=2 n+1$ for the CLEN. This feature has generally not been observed and described for $P 2_{1} / c$ clinopyroxenes. Experimental data indicated that with increasing pressure the $(h+k)=2 n+1$ reflections of low- $P$ CLEN would become weaker and then disappear at the phase transition (Prewitt, personal communication, 2001). Therefore, the possibility that low- $P$ CLEN $\left(P 2_{1} / c\right)$ transformed from high- $P$ CLEN $(C 2 / c)$ polymorph in the Dabie-Sulu terrane cannot be completely eliminated. The occurrence of clinoenstatite in garnet peridotite from some UHP terranes in China is being increasingly recognized; the exact mechanism to account for such new observations need to be investigated in conjunction with further experimental study.

\section{ACKNOWLEDGMENTS}

This research was supported by NSF EAR 95-06468 and 98-14468 (US), and by NSC87-2611-M-110-010 to Y.H.S. (Taiwan). We thank H.Y. Yang and the Department of Earth Sciences, National Cheng Kung University for using the Gatan 600 DuoMill. The TEM and EDS measurements were performed at the Center for High Technology Equipment, National Sun Yat-sen University, and we thank L.C. Wang for her technical assistance. We are grateful to Hexion Yang for his discussion and help. This manuscript has been critically reviewed and materially improved by H.W. Green, P.R. Buseck, A.B. Woodland, C.T. Prewitt, M. Welch, and W. G. Ernst.

\section{REFERENCES CITED}

Ames, L., Zhou, G., and Xiong, B. (1996) Geochronology and isotopic character of high-pressure metamorphism with implications for collision of the Sino-Korean and Yangtze cratons, central China. Tectonics, 15, 472-489.

Andersen, D.J. and Lindsley, D.H. (1988) Internally consistent solution models for Fe-Mg-Mn-Ti oxides: Fe-Ti oxides. American Mineralogist, 73, 714-726.

Angel, R.J. and Hugh-Jones, D.A. (1994) Equations of state and thermodynamic properties. Journal of Geophysical Research, 99, 19777-19783.

Angel, R.J., Chopelas, A., and Ross, N.E. (1992) Stability of high-density clinoenstatite at upper-mantle pressures. Nature, 358, 322-324.

Angel, R.J., Ross, T.L., Boffa-Ballaran, T., and Shaw, C. S. J. (2000) Crystal-chemical controls on high-pressure phase transitions in clinopyroxenes. Eos, Transactions, American Geophyiscal Union, 81, F1277.

Bozhilov, K.N., Green, H.W., and Dobrzhinetskaya, L. (1999) Clinoenstatite in the Alpe Arami peridotite: additional evidence of very high pressure. Science, 284, $128-132$.

Buddington, A.F. and Lindsley, D.H. (1964) Iron-titanium oxide minerals and synthetic equivalents. Journal of Petrology, 5, 310-357.

Buseck, P.R. and Iijima, S. (1975) High resolution electron microscopy of enstatite. II: Geology application. American Mineralogist, 60, 771-784.

Buseck, P.R., Nord, Jr. G.L., and Veblen, D.R. (1980) Subsolidus phenomena in pyroxenes. In C.T. Prewitt, Ed., Pyroxene, 7, 117-211. Reviews in Mineralogy, Mineralogical Society of America, Washington, D.C.

Cliff, G. and Lorimer, G.W. (1975) The quantitative analysis of thin specimens Journal of Microscopy, 103, 203-207.

Coe, R.S. and Kirby, S.H. (1975) The orthoenstatite to clinoenstatite transforma- tion by shearing and reversion by annealing mechanism and potential applications. Contributions to Mineralogy and Petrology, 52, 29-56.

Coe, R.S. and Muller, W.F. (1973) Crystallographic orientation of clinoenstatite produced by deformation of orthoenstatite. Science, 80, 64-66.

Dallwitz, W.B., Green, D.H., and Thompson, J.E. (1966) Clinoenstatite in a volcanic rock from the Cape Vogel area, Papua. Journal of Petrology, 7, 375-403.

Gasparik, T. (1990) Phase relations in the transition zone. Journal of Geophysical Research, 95, 15751-15769.

Hacker, B.R., Ratschbacher, L., Webb, L., Ireland, T., Walker, D., and Dong, S. (1998) Orogen-scale architecture of the ultrahigh-pressure Dabie-Hong'anTongbai Shan, China. Earth and Planetary Science Letters, 161, 215-230.

Hacker, B.R., Ratschbacher, L., Webb, L., McWilliams, M.O., Ireland, T., Calvet, A., Dong, S., Wenk, H.R., and Chateigner, D. (2000) Exhumation of ultrahighpressure continental crust in east central China. Journal of Geophysical Research, 105, 13339-13364.

Hugh-Jones, D.A., Woodland, A.B., and Angel, R.J. (1994) The structure of highpressure $C 2 / \mathrm{c}$ ferrosilite and crystal chemistry of high-pressure $C 2 / \mathrm{c}$ pyroxenes. American Mineralogist, 79, 1032-1042.

Katzir, Y., Avigad, D., Matthews, A., Garfunkel, Z., and Evans, B.W. (1999) Origin and metamorphism of ultrabasic rocks associated with a subducted continental margin, Naxos (Cyclades, Greece). Journal of Metamorphic Geology, 17, 301318.

Komatsu, M. (1980) Clinoenstatite in volcanic rocks from the Bonin Islands. Contributions to Mineralogy and Petrology, 74, 329-338.

Li, S., Chen, Y., Cong, B., Zhang, Z., Zhang R.Y., Liu, D., Hart, S.R., and Ge, N. (1993) Collision of the North China and Yangtze blocks and formation of coesitebearing eclogite: timing and processes. Chemical Geology, 109, 70-89.

Liou, J.G. and Zhang, R.Y. (1998) Petrogenesis of ultrahigh- $P$ garnet-bearing ultramafic body from Maowu, the Dabie Mountains, central China. The Island Arcs, 7, 115-134.

Liou, J.G., Zhang, R.Y., Eide, E.A., Maruyama, S., and Ernst, W.G. (1996) Metamorphism and tectonics of high- $P$ and ultrahigh- $P$ belts in the Dabie-Su-Lu region, eastern central China. In A. Yin and M. Harrison, Eds., The tectonic evolution of Asia, 666 p. Cambridge University Press, Cambridge, U.K.

McLaren, A.C. and Etheridge, M.A. (1976) A transmission electron microscope study of naturally deformed orthopyroxene. I. Slip mechanism. Contributions to Mineralogy and Petrology, 57, 163-177.

Medaris, L.G. Jr. (1999) Garnet peridotite in Eurasian HP and UHP terranes: A diversity of origins and thermal histories. International Geology Review, 41, 799-815.

Mori, T. (1978) Experimental study of pyroxene equilibria in the system CaO-MgOFeO-SiO ${ }_{2}$. Journal of Petrology, 19, 45-65.

Nakamura, Y. (1971) Equilibrium relations in Mg-rich part of the pyroxene quadrilateral. Mineralogical Journal, 6, 264-276.

Okay, A.I. (1994) Sapphirine and Ti-clinohumite in ultra-high-pressure garnet-pyroxenite and eclogite from Dabie Shan, China. Contributions to Mineralogy and Petrology, 116, 145-155.

Pacalo, R.E.G. and Gasparik, T. (1990) Reversal of the orthoenstatite-clinoenstatite transition at high pressure and high temperatures. Journal of Geophysical Research, 95, 15853-15858.

Papike, J.J., Prewitt, C.T., Sueno, S., and Cameron, M. (1973) Pyroxene: comparisons of real and ideal structural topologies. Zeitschrift für Kristallographie, 69, 254-273.

Revenaugh, J. and Jordan, T.H. (1991) Mantle layering from ScS reverberations 3. The upper mantle. Journal of Geophysical Research, 96, 19781-19810.

Ringwood, A.E. and Lovering, J.F. (1970) Significance of pyroxene-ilmenite intergrowths among kimberlite xenoliths. Earth and Planetary Science Letters, 7, 371-375.

Sameshima, T., Paris, J.-P., Black, P.M., and Heming, R.F. (1983) Clinoenstatitebearing lava from Nepoui, New Caledonia. American Mineralogist, 68, 10761082 .

Shinmei, T., Tomioka, N., Fujino, K., Kuroda, K., and Irifune, T. (1999) In situ Xray diffraction study of enstatite up to $12 \mathrm{GPa}$ and $1473 \mathrm{~K}$ and equations of state. American Mineralogist, 84, 1588-1594.

Smyth, J.R. (1974) Experimental study on the polymorphism of enstatite. American Mineralogist, 59, 345-352.

Thompson, R.N. (1975) Is upper-mantle phosphorus contained in sodic garnet? Earth and Planetary Science Letters, 26, 417-424.

Trommsdorff, V. and Wenk, H.R. (1968) Terrestrial metamorphic enstatite in kinks of bronzite crystals. Contributions to Mineralogy and Petrology, 19, 158-169.

Turner, F.J., Heard, H., and Grigges, D.T. (1960) Experimental deformation of enstatite and accompanying inversion to clinoenstatite. Report of 21 st International Geological Congress, Copenhagen, 18, 399-408.

Ulmer, P. and Stalder, R., (2001) The $\mathrm{Mg}(\mathrm{Fe}) \mathrm{SiO}_{3}$ orthoenstatite-clinoenstatite transitions at high pressures and temperatures determined by Raman-spectroscopy on quenched samples. American Mineralogist, 86, 1267-1274.

Ven Roermund, H.L.M., Drury, M.R., Barnhoorn, A., and De Ronde, A.A. (2000) Super-silicic garnet microstructures from an orogenic garnet peridotite, evidence for an ultra-deep ( $>6 \mathrm{GPa}$ ) origin. Journal of Metamorphic Geology, 18, $135-147$. 
Woodland, A.B. and Angel, R.J. (1997) Reversal of the orthoferrosilite-high- $P$ clinoferrosilite transition, a phase diagram for $\mathrm{FeSiO}_{3}$ and implications for the mineralogy of the Earth's upper mantle. European Journal of Mineralogy, 9, $245-254$.

Yang, J., Godard, G., Kienast, J.R., Lu, Y., and Sun, J. (1993) Ultrahigh-pressure (60 kbar) magnesite-bearing garnet peridotites from northeastern Jiangsu, China. Journal of Geology, 101, 541-554.

Ye, K., Cong, B., and Ye, D. (2000) The possible subduction of continental material to depths greater than $200 \mathrm{~km}$. Nature, 407, 734-736.

Zhang, R.Y., Liou, J.G., and Bolin, B.L. (1995) Talc-, magnesite- and Ti-clinohumitebearing ultrahigh-pressure mafic and ultramafic complex in the Dabie Mountains, China. Journal of Petrology, 36, 1011-1037.

Zhang, R.Y., Shu, J.F., Mao, H.K., and Liou, J.G. (1999) Magnetite lamellae in olivine and clinohumite from Dabie UHP ultramafic rocks, central China. American Mineralogist, 84, 564-569.

Zhang, R.Y., Liou, J.G., Yang, J.S., and Yui, T-F. (2000) Petrochemical constraints for dual origin of garnet peridotites from the Dabie-Sulu UHP terrane, easterncentral China. Journal of Metamorphic Geology, 18, 149-166.

Zhang, Z., Xu, Z., and Xu, H. (2000) Petrology of ultrahigh-pressure eclogites from the ZK703 drillhole in the Donghai, eastern China. Lithos, 52, 35-50.

MANUSCRIPT RECEIVED FEBRUARY 19, 2001

MANUSCRIPT ACCEPTED FEBRUARY 4, 2002

MANUSCRIPT HANDLED BY MARK WELCH 